N. V. Hetsko, I. Y. Krynytska

I. Horbachevsky Ternopil National Medical University, Ukraine

THE CHANGES OF C-REACTIVE PROTEIN AND TUMOR NECROSIS FACTOR- $\alpha$ CONTENT IN RATS OF DIFFERENT AGE WITH MODELED SECOND-HAND TOBACCO SMOKING COMBINED WITH PROLONGED TREATMENT OF MONOSODIUM GLUTAMATE

The World Health Organization considers tobacco smoke as a global health and social problem. The active use of food supplements is ambiguous as regards human health and safety. So, the study of molecular mechanisms of toxicity of isolated and combined action of tobacco smoking and monosodium glutamate is one of the topical issues of modern science.

The study aimed to determine changes in the C-reactive protein and tumor necrosis factor- $\alpha$ of blood serum in rats under secondhand tobacco smoking combined with a long-term monosodium glutamate injection in the age aspect.

Experiments were carried out on 64 outbred white male rats divided into the following groups: I - control group; II - rats with modeled secondhand tobacco smoking; III - rats, which were injected with monosodium glutamate; IV - rats with modeled secondhand tobacco smoking combined with the monosodium glutamate injection. Blood serum TNF- $\alpha$ and CRP content were performed by enzymelinked immunosorbent assay (ELISA) Kit developed by RayBiotech (USA) following the manufacturer's protocol on a Multiscan FC analyzer (Finland).

The findings suggest that under the combined action of secondhand tobacco smoke and monosodium glutamate, the content of TNF- $\alpha$ increased by 2.9 times $(\mathrm{p}<0.001)$ ) vs control group and by $32.3 \%(\mathrm{p}<0.002)$ exceeded the data under the isolated action of secondhand tobacco smoke. Regarding the CRP, this indicator increased by $45.5 \%$ ( $\mathrm{p}<0.001$ ) vs control group. Secondhand tobacco smoke combined with monosodium glutamate use did not cause significant changes vs the isolated effect of tobacco smoke. As regards age, the systemic inflammatory response was more pronounced in immature rats.

Key words: tobacco smoke, monosodium glutamate, age, inflammation.

Надійшла 26.03.2020.

УДК 591.111: (597.551.2+ 597.552.1) : 546.72

doi: $10.25128 / 2078-2357.20 .1-2.8$

\author{
В. О. ХОМЕНЧУК, О. О. РАБЧЕНЮК, В. В. ФУТРИК, В. З. КУРАНТ
}

Тернопільський національний педагогічний університет імені Володимира Гнатюка

вул. М. Кривоноса, 2, Тернопіль, 46027

e-mail: khomenchuk@tnpu.edu.ua

\title{
ОСОБЛИВОСТІ ОСМОТИЧНОЇ РЕЗИСТЕНТНОСТІ ЕРИТРОЦИТІВ ТА ВМІСТУ ГЕМОГЛОБІНУ У КРОВІ РИБ ЗА ДIÏ ФЕРУМУ (III)
}

Досліджено осмотичну резистентність еритроцитів та вміст гемоглобіну в крові коропа та щуки за дії 2 та 5 рибогосподарських гранично-допустимих концентрацій (ГДК) іонів $\mathrm{Fe}^{3+}$. Показано, що ці характеристики насамперед залежать від виду риб та концентрації Феруму (III) у воді.

Ключові слова: короп, щука, гемоглобін, осмотична резистентність еритроцитів, Ферум.

Ферум є одним з найбільш поширених елементів у земній корі, проте його концентрація в природних водах дуже мала [13]. Разом 3 тим відомо, що біоконцентрування Феруму гідробіонтами, включно рибами, здійснюється за низьких концентрацій металу і $є$ важливим 3 
екологічної точки зору [10]. Однак його акумулювання може становити потенційну небезпеку та призводити до хронічного чи гострого отруєння організму.

3 огляду на це, актуальним є пошук біомаркерних показників в організмі риб, які б давали змогу оцінити негативні наслідки дефіциту чи надлишку Феруму. Такі дослідження також допоможуть оцінити рівень забрудненості водного середовища сполуками Феруму, адже риби $є$ цінними біоіндикаторами [11].

Кров є багатофункціональною системою, а зміна гематологічних показників може об'єктивно відображати стан організму прісноводних риб [12]. Однією з основних мішеней дії металів $\epsilon$ формені елементи крові. У риб вони чутливі до дії низки токсикантів неорганічної та органічної природи, включно металів [9].

Для функціонування гемоглобіну, що міститься в еритроциті, важлива цілісність останнього. Однією з характеристик еритроцитів є осмотична резистентність, яка формується в результаті дії на організм зовнішніх і внутрішніх чинників. Її зниження відбувається внаслідок змін структурних і функціональних властивостей мембран еритроцитів, що виникають при старінні організму, захворюваннях, токсичних впливах тощо [8].

Особливий інтерес до досліджень мембрани еритроцитів пов'язаний перш за все з тим, що ці клітини беруть участь у процесах, пов'язаних з підтриманням гомеостазу на рівні цілого організму [4].

При порушенні осмотичної резистентності відбувається зниження стійкості клітин до деформації, знижується активність багатьох ферментів і гормонів, що прискорює процеси старіння і руйнування клітин [2].

У роботі було досліджено осмотичну резистентність еритроцитів та вміст гемоглобіну в крові коропа та щуки за дії підвищених концентрацій іонів $\mathrm{Fe}^{3+}$, що, на наш погляд, представляє інтерес для оцінки фізіологічного стану риб та якості води за умов забруднення водотоків металами.

\section{Матеріал і методи досліджень}

Дослідження проведено на дворічках коропа (Cyprinus carpio L.) i щуки (Esox lucius L.) 3 середньою масою 300-350 г. Дослідних риб виловлювали зі ставків Тернопільського рибкомбінату, в урочищі Залісці. Для експериментального витримування риб використовували відстояну водопровідну воду. Вміст кисню у воді акваріумів підтримували на рівні 7,0-8,0 мг/л. Перед дослідом риб аклімували 3 доби в басейнах об'ємом 2 м³ $^{3}$.

В експериментах риб утримували в лабораторних акваріумах об'ємом 200 л з розрахунку 40 дм $^{3}$ на одну особину. Вивчали вплив на риб іонів $\mathrm{Fe}^{3+}$ в концентраціях 0,2 і 0,5 мг/дм³ ${ }^{3}$ що відповідали 2 та 5 рибогосподарським ГДК. Необхідні концентрації іонів металу у воді створювали внесенням солі $\mathrm{FeCl}_{3} \times 6 \mathrm{H}_{2} \mathrm{O}$ кваліфікації «х.ч.». Контролем служили величини досліджуваних показників тканин риб, які перебували у воді акваріумів без додавання Феруму (III). 3 метою запобігання хронічного впливу на риб ї власних екзометаболітів воду в акваріумах змінювали щодводобово. Період утримування риб у токсичних умовах становив 14 діб.

Після зазначеного терміну відбирали кров для дослідження із серця риб. Голку для взяття крові $з$ метою запобігання коагуляції попередньо обробляли розчином гепарину. Досліди виконувалась відповідно до правил Європейської конвенції про гуманне ставлення до лабораторних тварин та «Загальних принципів експериментів на тваринах», ухвалених Першим національним конгресом з біоетики.

Осмотичну резистентність еритроцитів риб визначали за універсальним методом в модифікації Ідельсона Л.І. [1]. Для цього в центрифужні пробірки доливали по 5 мл робочих розчинів хлориду натрію 3 концентрацією від 0,60 до $0,10 \%$. У кожну пробірку додавали по 0,02 мл перемішаної гепаринізованої крові та залишали при кімнатній температурі на 30 хв, після чого центрифугували при 2000 об/хв протягом 5 хв. 3 кожної пробірки зливали надосадову рідину і вимірювали на фотоелектроколориметрі при довжині хвилі 540 нм проти холостої проби. Холоста проба - надосадова рідина в пробірці, що містить $0,6 \%$ розчин натрій хлориду. За $100 \%$ гемоліз приймали гемоліз в пробірці, що містить $0,1 \%$ розчин хлориду натрію. Обчислювали відсоток гемолізу в кожній пробірці за формулою: 
Відсоток гемолізу $=\mathrm{Ex} * 100 / \mathrm{E}_{1}$, де

$\mathrm{E}_{1}$ - екстинкція надосадової рідини в пробірці з $0,1 \%$ розчином хлориду натрію;

$\mathrm{E}_{\mathrm{X}}$ - екстинкція досліджуваної проби;

Рівень гемоглобіну досліджували гемоглобінціанідним методом [3]. Усі одержані дані піддавали статистичній обробці з використанням пакету Microsoft Exel.

\section{Результати досліджень та їх обговорення}

Важливе значення при оцінці осмотичної резистентності еритроцитів має значення концентрацій натрій хлориду початку (OR-min) i закінчення (OR-max) гемолізу. Аналіз отриманих даних показав, що у еритроцитах крові коропів контрольної групи гемоліз починається при зниженні концентрації розчину хлориду натрію до $0,40 \%$ (рис. 1). Разом із тим за впливу 5 ГДК іонів $\mathrm{Fe} 3+$ було відмічено зниження OR-min до 0,5\% розчину $\mathrm{NaCl}$. Уже за цієї концентрації мало місце руйнування більше $5 \%$ еритроцитів. Така ж тенденція відзначається при подальшому зниженні концентрації солі до $0,4 \%$, коли було відмічене руйнування $33,0 \%$ формених елементів крові за дії 5 ГДК проти $22,5 \%$ у контрольній групі. За концентрації гіпотонічного розчину $0,3 \%$ відбувається гемоліз $82,9 \%, 84,1 \%$ та $86,2 \%$ еритроцитів у контрольній групі і за дії 2 та 5 ГДК іонів Fe3+ відповідно. Практично повністю руйнуються всі еритроцити при розведенні розчину до концентрації $0,2 \%$ у всіх групах коропів (рис. 1). Отже, можна відзначити, що найнижчою осмотичною резистентністю володіють еритроцити коропів, що зазнавали впливу 5 ГДК Феруму (ІІІ). Очевидно, високі концентрації призводять до порушення цілісності мембрани, що обумовлено накопиченням прихованих структурних пошкоджень у білково-ліпідному каркасі мембран низько- і високостійких еритроцитів [7].

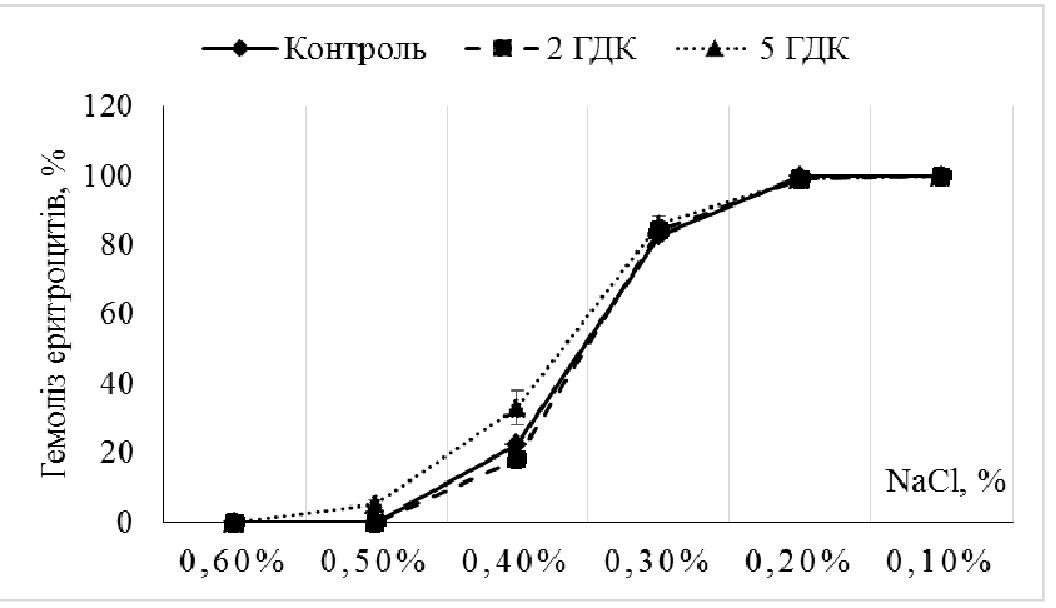

Рис. 1. Осмотична резистентність еритроцитів коропа за дії підвищених концентрацій $\mathrm{Fe}^{3+}(\mathrm{M} \pm \mathrm{m}, \mathrm{n}=5)$

При дослідженні осмотичної резистентності крові еритроцитів щуки за впливу підвищених концентрацій були помічені інші закономірності (рис. 2). Як у контрольній, так і дослідних групах спостерігали початок гемолізу вже у $0,5 \%$ гіпотонічному розчині. Ступінь руйнування еритроцитів при цьому становив 30,0\% у контрольній групі, $14,0 \%$ за дії 2 ГДК іонів $\mathrm{Fe}^{3+}$ та 18,6\% за впливу 5 ГДК Феруму (III). Слід відзначити, що в контролі спостерігали нижчі значення осмотичної резистентності еритроцитів крові щуки порівняно 3 дослідними групами риб. Так, за концентрації розчину натрій хлориду $0,4 \%$ осмотична резистентність еритроцитів була на $25 \%$ при 2 ГДК та на $130 \%$ за дії 5 ГДК іонів $\mathrm{Fe}^{3+}$ вищою щодо контрольної групи риб. У гіпотонічному розчині з концентрацією $\mathrm{NaCl} 0,3 \%$ ступінь гемолізу еритроцитів крові щуки становив 93,1\%, 76,0\% та 62,1\% у групах контролю, 2 ГДК та 5 ГДК відповідно. Як i в коропа, за концентрації $0,2 \%$ було відмічене $100 \%$ руйнування червоних кров'яних тілець у щуки. Можна припустити, що підвищення осмотичної резистентності еритроцитів 3 підвищенням концентрації іонів Феруму у водному середовищі пов'язано 3 підвищенням щільності біліпідного шару плазматичної мембрани еритроцитів. 
Зростання осмотичної резистентності еритроцитів щуки за впливу високих концентрацій може бути обумовлено посиленням пероксидного окиснення ліпідів (ПОЛ) [6]. Інтенсифікація ПОЛ клітинних мембран викликає ущільнення ліпідного шару, збільшення його мікров'язкості, скорочення площі білокліпідних взаємодій, зміну активності ферментних систем та мембранної проникності [5].

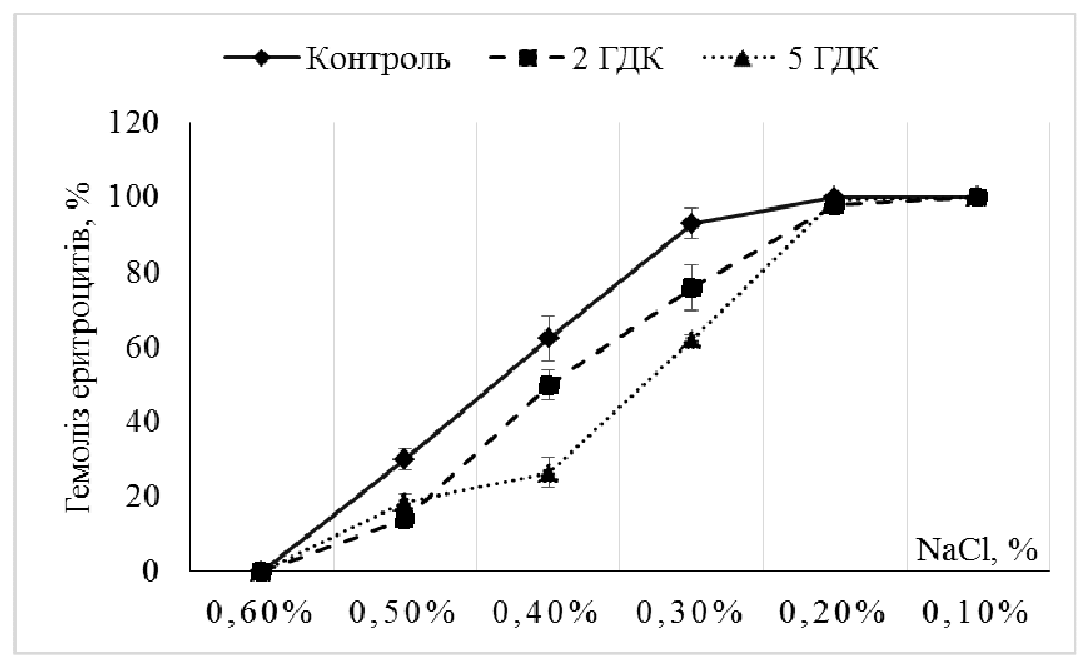

Рис. 2. Осмотична резистентність еритроцитів щуки за дії підвищених концентрацій $\mathrm{Fe}^{3+}(\mathrm{M} \pm \mathrm{m}, \mathrm{n}=5)$

Відмінності в концентраціях гіпотонічних розчинів, що характеризують початок гемолізу еритроцитів у коропа та щуки, а також різна осмотична стійкість плазматичних мембран еритроцитів риб за дії підвищених концентрацій іонів $\mathrm{Fe}^{3+}$ вказують на видоспецифічність досліджуваних параметрів та різні механізми адаптації формених елементів риб до несприятливих чинників водного середовища.

Рівень гемоглобіну в коропа збільшується за впливу 5 ГДК іонів $\mathrm{Fe}^{3+}$, тоді як у щуки рівень пігменту достовірно знижується за даної концентрації іонів металу (рис. 3). За впливу 2 ГДК іонів металу достовірних змін кількості гемоглобіну у крові досліджуваних видів риб виявлено не було.

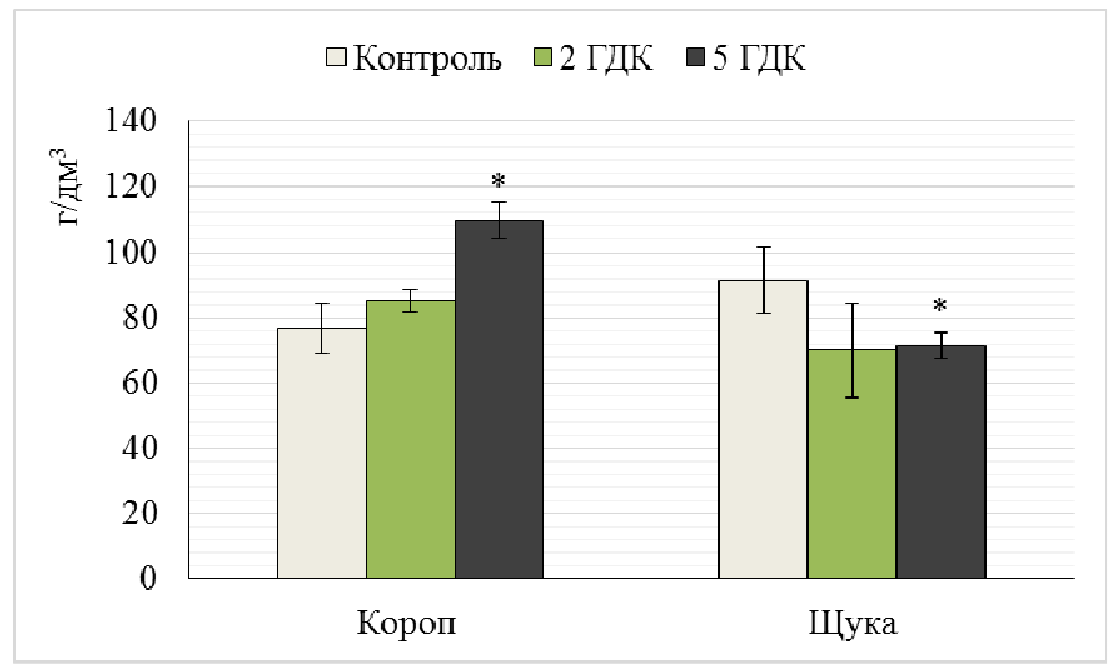

Рис. 3. Вміст гемоглобіну у крові риб за дії іонів $\mathrm{Fe}^{3+}(\mathrm{M} \pm \mathrm{m}, \mathrm{n}=5)$

Очевидно, відмінності обумовлені екологічними та фізіолого-біохімічними особливостями цих видів риб. 


\section{Висновки}

Підвищені концентрації іонів $\mathrm{Fe}^{3+}$ призводять до змін осмотичної резистентності еритроцитів та вмісту гемоглобіну в крові коропа і щуки. Відзначено, що високі концентрації Феруму (5 ГДК) у коропа призводять до зниження стійкості мембран еритроцитів, а у щуки до підвищення даного параметру. Видоспецифічністю характеризуються i зміни вмісту гемоглобіну у крові досліджуваних видів риб. Мало місце зростання кількості пігменту у крові коропа та зниження його кількості у щуки за дії 5 ГДК іонів металу.

1. Идельсон Л. И. Справочник по функциональной диагностике / под ред. И. А. Кассирского. М. : Медицина, 1970. С. 401.

2. Изергина Е. Е., Изергин И. Л. К вопросу об осмотической резистентности эритроцитов периферической крови молоди кеты (Oncorhynchus Keta). Исследования водных биологических ресурсов Камчатки и северо-западной части Тихого океана. 2011. Вып. 23. С. 18-25.

3. Кушаковський М. С. Клинические формы повреждения гемоглобина. Л. : Медицина, 1968. 324 с.

4. Морозова В. Т., Луговская С. А., Почтарь М. Е. Эритроциты : структура, функции, клиникодиагностическое значение. Клиническая лабораторная диагностика. 2007. № 10. С. 21-35.

5. Мухомедзянова С. В., Пивоваров Ю. И., Богданова О. В., Дмитриева Л. А., Шулунов А. А. Липиды биологических мембран в норме и патологии (обзор литературы). Acta biomedica scientifica. 2017, Том 2, № 5, Часть 1. С. 43-49

6. Особливості перекисного окиснення ліпідів риб за умов підвищених концентрацій йонів $\mathrm{Fe}^{3+}$ /Рабченюк О. О. та ін. Наук. зап. Терноп. наи. пед. ун-ту. Сер. Біологія. 2018. № 3-4 (74). С. 38-46. За авторами

7. Попова И. Е. Изучение структурных свойств эритроцитов крови новорожденных при оксидативном стрессе, вызванном гипоксией: дис. ... д-ра биол. наук: . Воронеж, 2007. 250 с.

8. Сравнительный анализ осмотической резистентности эритроцитов у различных по экологии Teleostei /Андреева А. М. и др. Вестник Санкт-Петербургского университета. 2013. Сер. 3. Вып. 4. C. 3-13. За авторами

9. Devi B., Radhakrishnaiah K. Changes in total lipids in the osmoregulatory organs of the fresh concentrations of mercury. Z. Aggew. Zool., 1990. Vol. 77, no. 1. P. 121-126.

10. Gregorovic' G., Kralj-Klobucªr N., Kopiar N. Histological and morphometric study on the tissue and cellular distribution of iron in carp Cyprinus carpio L. During chronic waterborne exposure. J. Fish Biol. 2008. Vol. 72. P. 1841-1846.

11. Rayment G. E., Barry G. A. Indicator tissues for heavy metal monitoring - additional attributes. Marine Pollution Bulletin. 2000. Vol. 41, № 7-12. P. 353-358.

12. Serpunin G. G., Likhatchyova O. A. Use of the ichthyohaematological studies in ecological monitoring of the reservoirs. Acta Vet. Brno. 1998. Vol. 67. P. 339-345.

13. Wood Chris M., Farrell Anthony P., Brauner Colin J. Homeostasis and toxicology of essential metals edited. Fish Physiology. London : Academic Press. 2011. Vol. 31. Part A. P. 1-497.

\section{References}

1. Idel'son L. I. V kn. : Spravochnik po funkcional'noj diagnostike / Pod red. I. A. Kassirskogo. - M., Medicina, 1970. S. 401. [in Russian]

2. Izergina E. E., Izergin I. L. K voprosu ob osmoticheskoj rezistentnosti jeritrocitov perifericheskoj krovi molodi kety (Oncorhynchus Keta). Issledovanija vodnyh biologicheskih resursov Kamchatki i severozapadnoj chasti Tihogo okeana. 2011, vyp. 23. S. 18-25. [in Russian]

3. Kushakovs'kij M.S. Klinicheskie formy povrezhdenija gemoglobina. L. : Medicina, 1968. 324 s. [in Russian]

4. Morozova V. T., Lugovskaja S. A., Pochtar' M. E. Jeritrocity : struktura, funkcii, kliniko-diagnosticheskoe znachenie. Klinicheskaja laboratornaja diagnostika. 2007. № 10. S. 21-35. [in Russian]

5. Muhomedzjanova S. V., Pivovarov Ju. I., Bogdanova O. V., Dmitrieva L. A., Shulunov A. A. Lipidy biologicheskih membran v norme i patologii (obzor literatury). Acta biomedica scientifica. 2017, Tom 2, № 5, Chast' 1. S. 43-49. [in Russian]

6. Osoblyvosti perekysnoho okysnennia lipidiv ryb za umov pidvyshchenykh kontsentratsii yoniv $\mathrm{Fe}^{3+}$. Rabcheniuk O. O., Khomenchuk V. O., Stanislavchuk H. V., Zghurska S. B. Kurant V. Z. Nauk. zap. Ternop. nats. ped. un-tu. Ser. Biolohiia. 2018. № 3-4 (74). S. 38-46. [in Ukrainian]

7. Popova I. E. Izuchenie strukturnyh svojstv jeritrocitov krovi novorozhdennyh pri oksidativnom stresse, vyzvannom gipoksiej: dis. ... d-ra biol. nauk. Voronezh, 2007. 250 s. [in Russian] 
8. Sravnitel'nyj analiz osmoticheskoj rezistentnosti jeritrocitov u razlichnyh po jekologii Teleostei. Andreeva A. M., Rjabceva I. P., Rudneva I. I., Shajda V. G., Lamash N. E., Dmitrieva A. Je. Vestnik SanktPeterburgskogo universiteta. 2013. Ser. 3. Vyp. 4. S. 3-13. [in Russian]

9. Devi B., Radhakrishnaiah K. Changes in total lipids in the osmoregulatory organs of the fresh concentrations of mercury. Z. Aggew. Zool., 1990. Vol. 77, no. 1. P. 121-126.

10. Gregorovic' G., Kralj-Klobuc`ar N., Kopiar N. Histological and morphometric study on the tissue and cellular distribution of iron in carp Cyprinus carpio L. During chronic waterborne exposure. J. Fish Biol. 2008. Vol. 72. P. 1841-1846.

11. Rayment G. E., Barry G. A. Indicator tissues for heavy metal monitoring - additional attributes. Marine Pollution Bulletin. 2000. Vol. 41, № 7-12. P. 353-358.

12. Serpunin G. G., Likhatchyova O. A. Use of the ichthyohaematological studies in ecological monitoring of the reservoirs. Acta Vet. Brno. 1998. Vol. 67. P. 339-345.

13. Wood Chris M., Farrell Anthony P., Brauner Colin J. Homeostasis and toxicology of essential metals edited. Fish Physiology. London : Academic Press. 2011. Vol. 31. Part A. P. 1-497.

V. O. Khomenchuk, O. O. Rabcheniuk, V. V. Futryk, V. Z. Kurant

Ternopil Volodymyr Hnatiuk National Pedagogical University, Ukraine

FEATURES OF OSMOTIC RESISTANCE OF ERYTHROCYTES AND HEMOGLOBIN CONTENT IN THE BLOOD OF FISH UNDER THE ACTION OF FERUM (III)

The osmotic resistance of erythrocytes and the content of hemoglobin in the blood of carp (Cyprinus carpio L.) and pike (Esox lucius L.) under the action of $\mathrm{Fe}^{3+}$ ions at concentrations of 0.2 and 0.5 $\mathrm{mg} / \mathrm{dm}^{3}$, were under study which corresponded to 2 and 5 maximum permissible concentration (MPC). The research demonstrated that increased concentrations of $\mathrm{Fe}^{3+}$ ions lead to changes in the osmotic resistance of erythrocytes and the content of hemoglobin in the blood of carp and pike. The findings suggest that high concentrations of Iron (5 MPC) in carp lead to a decrease in the resistance of erythrocyte membranes, and in pike it led to increased osmotic resistance of erythrocytes, which is apparently due to different mechanisms of adaptation of fish erythrocyte membranes to adverse aquatic environment. Species-specificity is also characterized by changes in the content of hemoglobin in the blood of fish species which were researched. An increased amount of pigment in the blood of carp and a decreased amount of hemoglobin in pike under the action of 5 MPC of metal ions was established. The obtained results can be used to assess the physiological condition of fish and water quality under conditions of contamination of watercourses with metals.

Key words: carp, pike, hemoglobin, osmotic resistance of erythrocytes, Iron.

Надійшла 05.05.2020. 